\title{
Measured Energy Savings from the Application of Reflective Roofs in 3 AT\&T Regeneration Buildings
}

\author{
Hashem Akbari and Leo Rainer \\ Heat Island Group \\ Lawrence Berkeley National Laboratory \\ Berkeley, CA 94720
}

November, 2000

This work was supported by AT\&T, the U.S. Environmental Protection Agency (EPA) under IAG No. DW89938442-01-2, and by the Assistant Secretary for Energy Efficiency and Renewable Energy, Building Technologies, of the U.S. Department of Energy (DOE) under contract No. DE-AC03-76SF00098. 


\title{
Measured Energy Savings from the Application of Reflective Roofs in 3 AT\&T Regeneration Buildings
}

\author{
Hashem Akbari and Leo Rainer ${ }^{1}$ \\ Heat Island Group \\ Lawrence Berkeley National Laboratory \\ Berkeley, CA 94720
}

\section{Abstract}

Energy use and environmental parameters were monitored in three AT\&T regeneration buildings during the summer of 2000. These buildings are constructed with concrete and are about $14.9 \mathrm{~m}^{2}$ in size $\left(160 \mathrm{ft}^{2} ; 10 \mathrm{x} 16 \mathrm{ft}\right)$. The buildings were initially monitored for about $11 / 2$ months to establish a base condition. Then, the roofs of the buildings were painted with a white coating and the monitoring was continued. The original roof reflectances were about $26 \%$; after the application of roof coatings the reflectivities increased to about $72 \%$.

In two of these buildings, we monitored savings of about $0.5 \mathrm{kWh}$ per day $\left(30 \mathrm{Wh} / \mathrm{m}^{2}\right.$ per day [ $\left.3 \mathrm{Wh} / \mathrm{ft}^{2}\right]$ ). The third building showed a reduction in air-conditioning energy use of about $13 \mathrm{kWh}$ per day $\left(860 \mathrm{Wh} / \mathrm{m}^{2}\left[80 \mathrm{Wh} / \mathrm{ft}^{2}\right]\right)$. These savings probably resulted from the differences in the performance (EER) of the two dissimilar AC units in this building.

The estimated annual savings for two of the buildings are about $125 \mathrm{kWh}$ per year $(8.6$ $\left.\mathrm{kWh} / \mathrm{m}^{2}\left[0.8 \mathrm{kWh} / \mathrm{ft}^{2}\right]\right)$; at a cost of $\$ 0.1 / \mathrm{kWh}$, savings are about $\$ 12.5$ per year. Obviously, it costs significantly more than this amount to coat the roofs with reflective coating, particularly because of the remote locations of these buildings. However, since the prefabricated roofs are already painted green at the factory, painting them with white (reflective) color would bring no additional cost. Hence the payback time for having reflective roofs is nil, and the reflective roofs save an accumulated $3750 \mathrm{kWh}$ over 30 years of the life of the roof.

\section{Introduction}

Cool roofs reflect most of the incoming sunlight and keep the roof surface at a lower temperature than that of regular (hot) roofs (roofs that absorb most of the incoming radiation). A lower roof surface temperature would lead to lower heat conduction into the building and hence reduce cooling loads of the building.

Several field studies have documented measured energy savings that result from increasing the solar reflectivity of roofs. Akbari et al. (1997) reported monitored cooling energy savings of $46 \%$ and peak power savings of $20 \%$ by increasing the roof albedo of two identical school bungalows in Sacramento. More recent studies have documented measured savings of $12-18 \%$ in two commercial buildings in California (Konopacki et al. 1998) and an average of 19\% in eleven Florida residences (Parker et al. 1998) by applying reflective coatings on roofs. Parker et al. (1997) have also monitored seven retail stores within a strip mall in Florida before and after applying a high-albedo coating to the roof and measured a $25 \%$ drop in seasonal cooling energy use. Hildebrandt et al. (1998) observed daily AC savings of 17\%, 26\%, and 39\% in an office, museum and hospice with high-albedo

${ }^{1}$ Davis Energy Group, 123 C Street, Davis, CA 95616 
roofs in Sacramento. Akridge (1998) reported savings of $28 \%$ for an education building which had an unpainted galvanized roof coated with white acrylic. An office building in southern Mississippi was shown to save $22 \%$ after the application of a highly reflective coating (Boutwell and Salinas 1986).

In addition to field studies, computer simulations of cooling energy savings from an increased roof albedo have been documented in residential and commercial buildings in many studies (Konopacki and Akbari 1998, Akbari et al. 1998; Parker et al. 1998; and Gartland et al. 1996). Konopacki et al. (1997) estimated the direct energy savings potential from high-albedo roofs in eleven U.S. metropolitan areas. The results showed that three major building types account for over $90 \%$ of the annual electricity and monetary savings: old residences (55\%), new residences (15\%), and old/new office buildings and retail stores together (25\%). Furthermore, these three building types account for $93 \%$ of the total air-conditioned roof area. The regional savings were a function of energy savings in the air-conditioned building, stock of residential and commercial buildings, percentage of buildings that were air-conditioned, and the number of floors per building (roof area). Populous cities with an older low-rise building stock, in hot and sunny climates, and with a high level of AC saturation provided the highest savings potential for heat island reduction measures. Metropolitanwide savings were as much as $\$ 37 \mathrm{M}$ for Phoenix and \$35M in Los Angeles and as low as $\$ 3 \mathrm{M}$ in the heating-dominated climate of Philadelphia. The analysis of the urban scale energy savings potentials is further refined for three cities: Baton Rouge, LA; Sacramento, CA; and Salt Lake City, UT (Konopacki and Akbari 2000).

AT\&T maintains hundreds of small optical regeneration buildings every 12 miles along its national network of fiber-optic communications lines. These "regen" buildings contain optical amplification equipment that maintains the signal strength of digital communications sent through the fiber-optic cables. AT\&T is evaluating coating the roofs of these buildings with a white "ceramic" coating in order to reduce the cooling energy usage of the buildings. This study documents measured energy savings in three "regen" buildings. During the period from June to October 2000, we monitored the energy use in these buildings and conducted experiments to quantify the impact of roof reflectivity on the cooling energy use of the buildings.

\section{Description of Buildings}

Three sites across Nevada were selected for monitoring. Sites were selected so as to provide a range of locations, weather, and geography, but other factors that were considered were:

- $\quad$ ease of access (all are located close to a major access road);

- availability of a useable phone line for data downloading (some sites have a locator which will interfere with modem communication);

- uniformity of installed equipment (different sites have different amounts of equipment but all three selected have close to the same installed load).

The three sites selected were:

- Washoe (20 miles south of Reno)

- Battle Mountain (200 miles east of Reno)

- Carlin (60 miles east of Battle Mountain)

Each regen building consists of a $3.0 \mathrm{~m}$ wide $\mathrm{x} 4.9 \mathrm{~m}$ wide $\mathrm{x} 3.0 \mathrm{~m}$ high (10'x16'x10') prefabricated concrete structure with one access door (see Figure 1). The building shell consists of $12.5 \mathrm{~cm}$ 
(5") thick concrete with an exposed aggregate finish. The inside of the walls have $5 \mathrm{~cm}$ (2") of isocyanurate foam covered with $1.25 \mathrm{~cm}(1 / 2$ ") gypsum wallboard. The ceiling consists of $7.5 \mathrm{~cm}$ (3") of isocyanurate foam insulation covered with $1.25 \mathrm{~cm}\left(1 / 2^{\prime \prime}\right)$ gypsum wallboard. Above the ceiling is a $0.6 \mathrm{~m}$ (2') high attic passively ventilated by a $25 \mathrm{~cm}$ x $36 \mathrm{~cm}$ (10"x 14 ") louvered opening at each gable end. The roofs are painted gray-green.

Each regen building contains optical amplification equipment with a connected load of approximately $2.5 \mathrm{~kW}$. The equipment operates on $48 \mathrm{VDC}$ supplied by a bank of lead-acid batteries that are continually charged by the $120 \mathrm{VAC}$ supply. The buildings conditions are maintained between $18.3^{\circ} \mathrm{C}$ and $26.7^{\circ} \mathrm{C}\left(65^{\circ}\right.$ and $\left.80^{\circ} \mathrm{F}\right)$ by an environmental control panel which operates two throughthe-wall packaged terminal air-conditioners and a resistance heater (see Figure 2). The primary airconditioner is used to maintain $26.7^{\circ} \mathrm{C}\left(80^{\circ} \mathrm{F}\right)$ while the secondary air-conditioner is used only when the interior temperature exceeds $29.4^{\circ} \mathrm{C}\left(85^{\circ} \mathrm{F}\right)$. A seven-day interval timer set for $31 / 2$ days selects one of the two air-conditioners alternately as the primary unit so that they incur equal operating hours.

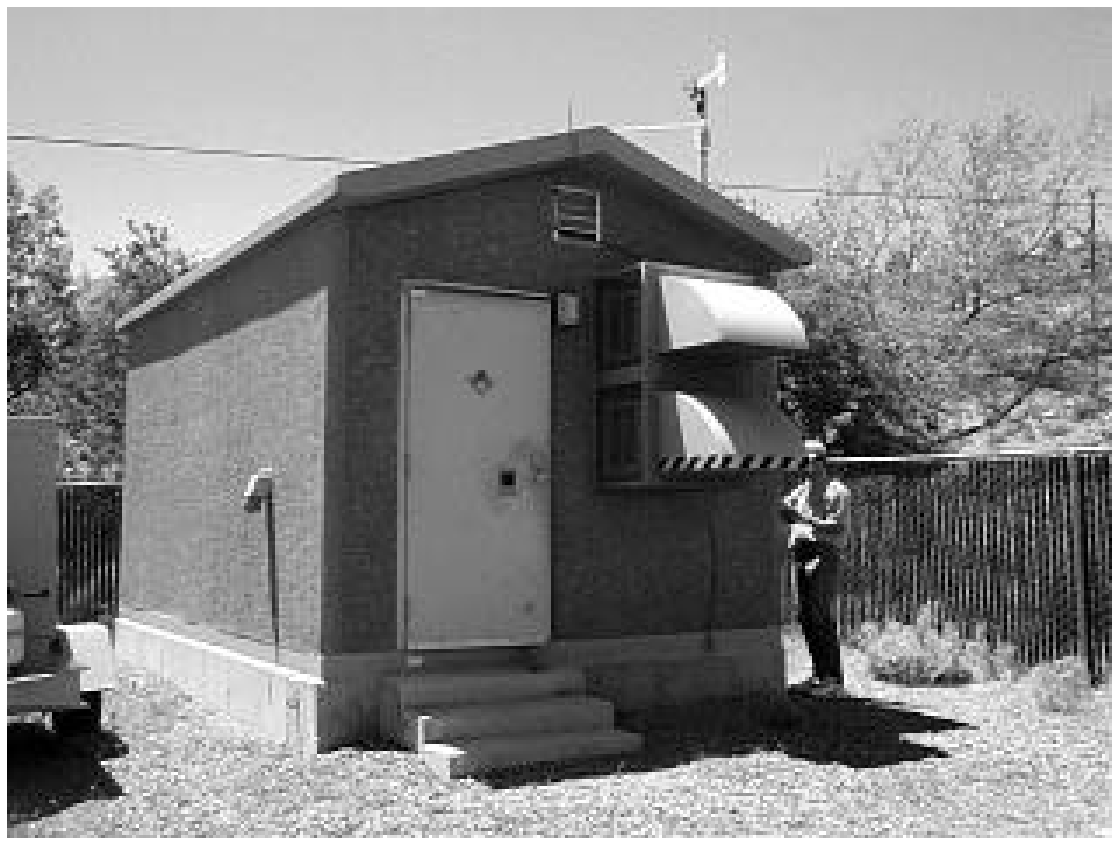

Figure 1: Typical Regen Building. 


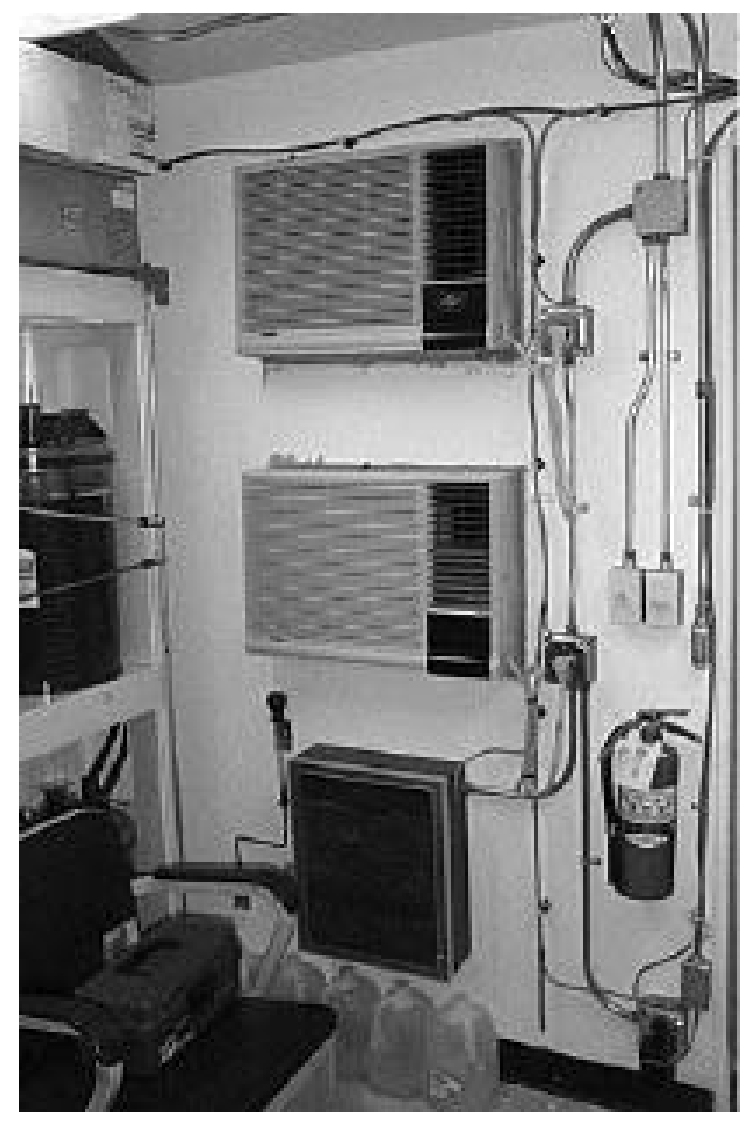

Figure 2: Air-conditioners and Resistance Heater

\section{Air-Conditioning Systems}

While each of the regen buildings is nearly identical, there are some differences in AC systems; the rate AC characteristics are summarized in Table 1. None of the AC systems have an economizer cycle. Table 1 also shows building orientations and the internal loads from equipment in each building.

Table 1: Site Characteristics.

\begin{tabular}{l|lllll}
\hline \multirow{2}{*}{ Site } & \multirow{2}{*}{ Front Faces } & $\begin{array}{l}\text { Internal } \\
\text { Load }(\mathrm{kW})\end{array}$ & MC System & & \\
\cline { 4 - 6 } & & & & $\begin{array}{l}\text { Capacity } \\
(\mathrm{kBtu} / \mathrm{h})\end{array}$ & EER \\
\hline Washoe & $\mathrm{NE}$ & 2.515 & Carrier YCB243D & 23,500 & 8.5 \\
& & & Carrier YCA213D & 21,000 & 9.2 \\
Battle & $\mathrm{NE}$ & 2.486 & 2 x Carrier YCB243D & 23,500 & 8.5 \\
$\begin{array}{l}\text { Mountain } \\
\text { Carlin }\end{array}$ & $\mathrm{SE}$ & 2.337 & $2 \times$ Carrier YCB243D & 23,500 & 8.5 \\
\hline
\end{tabular}




\section{Roof Surface Albedo}

For the existing roofs, a one-time measurement of roof surface albedo was performed at each site using a pyranometer to measure total downward and upward radiation parallel to the roof. Three measurements were taken at the center of each side of the roof and averaged. The roof albedo measurements for each site were highly consistent with the overall average measured at $26.2 \%$ (see Table 2).

Table 2: Summary of Albedo Measurements

\begin{tabular}{|c|c|c|c|c|c|c|c|c|}
\hline & \multicolumn{4}{|c|}{ Pre } & \multicolumn{3}{|c|}{ Post } & \\
\hline Site & Side & Down & $\mathrm{Up}$ & Albedo & Side & Down & $\mathrm{Up}$ & Albedo \\
\hline Washoe & $\mathrm{A}$ & 1035 & 267 & $25.8 \%$ & & & & \\
\hline & A & 1031 & 267 & $25.9 \%$ & & & & \\
\hline & A & 1034 & 263 & $25.5 \%$ & & & & \\
\hline & B & 1038 & 269 & $26.0 \%$ & $B$ & 935 & 672 & $71.9 \%$ \\
\hline & B & 1055 & 271 & $25.7 \%$ & B & 925 & 667 & $72.1 \%$ \\
\hline & B & 1047 & 268 & $25.6 \%$ & B & 926 & 671 & $72.5 \%$ \\
\hline Average & & & & $25.7 \%$ & & & & $72.2 \%$ \\
\hline Battle & $\mathrm{A}$ & 883 & 235 & $26.6 \%$ & & & & \\
\hline Mountain & $A$ & 867 & 236 & $272 \%$ & & & & \\
\hline & $\mathrm{A}$ & 886 & 234 & $26.4 \%$ & & & & \\
\hline & B & 1042 & 268 & $25.7 \%$ & & & & \\
\hline & B & 1062 & 266 & $25.0 \%$ & & & & \\
\hline & B & 1076 & 268 & $24.9 \%$ & & & & \\
\hline Average & & & & $26.0 \%$ & & & & \\
\hline Carlin & A & 1043 & 285 & $27.3 \%$ & & & & \\
\hline & A & 1032 & 279 & $27.1 \%$ & & & & \\
\hline & A & 1010 & 281 & $27.8 \%$ & & & & \\
\hline & B & 795 & 199 & $25.0 \%$ & & & & \\
\hline & B & 750 & 203 & $27.1 \%$ & & & & \\
\hline & B & 750 & 205 & $27.3 \%$ & & & & \\
\hline Average & & & & $26.9 \%$ & & & & \\
\hline $\begin{array}{l}\text { Overall } \\
\text { Average }\end{array}$ & & & & $26.2 \%$ & & & & \\
\hline
\end{tabular}

The roof the buildings were covered with a white coating during July 26-28. Out initial plan was to measure the reflectivity of the white coating during the decommissioning of the monitoring equipment (planned for the first week of October). Unfortunately, at the time of the decommissioning due to cloudy weather conditions, we were only able to measure the albedo of the coated roof for the building in Washoe. However, we believe that, since all the roofs are of the same material with the same roughness, the reflectivity of all coated roofs after about 2 months is about $72 \%$. 


\section{Instrumentation and Data Acquisition Systems}

Data monitoring equipment was installed on June 7-9, 2000. Table 3 shows the 13 data points installed with their locations shown in Figure 3. All variables were measured every 15 seconds with the average values recorded on a 15-minute basis. Data were downloaded nightly via modem.

Table 3: Monitoring Points

\begin{tabular}{l|llll}
\hline Point & Name & Location & Purpose & Signal \\
\hline 1 & TRS-A & Roof surface at A & Roof surface temperature & type T \\
2 & TRS-B & Roof surface at B & Roof surface temperature & type T \\
3 & TRU-A & Roof underside at A & Roof underside temperature & type T \\
4 & TRU-B & Roof underside at B & Roof underside temperature & type T \\
5 & TAA & Middle of attic & Attic air temperature & type T \\
6 & TAI & Wall at enviro panel & Interior air temperature & type T \\
7 & TAO & Weather tower & Outdoor dry bulb temperature & $0-1$ VDC \\
8 & RHO & Weather tower & Outdoor relative humidity & $0-1$ VDC \\
9 & WSPD & Weather tower & Wind speed & Pulse \\
10 & WDIR & Weather tower & Wind direction & $0-5$ VDC \\
11 & HSOL & Weather tower & Horizontal solar radiation & $0-100$ uA \\
12 & WAC & Panelboard & Total AC power & Pulse \\
13 & WTOT & Panelboard & Total building power & Pulse \\
\hline
\end{tabular}

ATAT REGEN BHILDING MONITORING PLAN

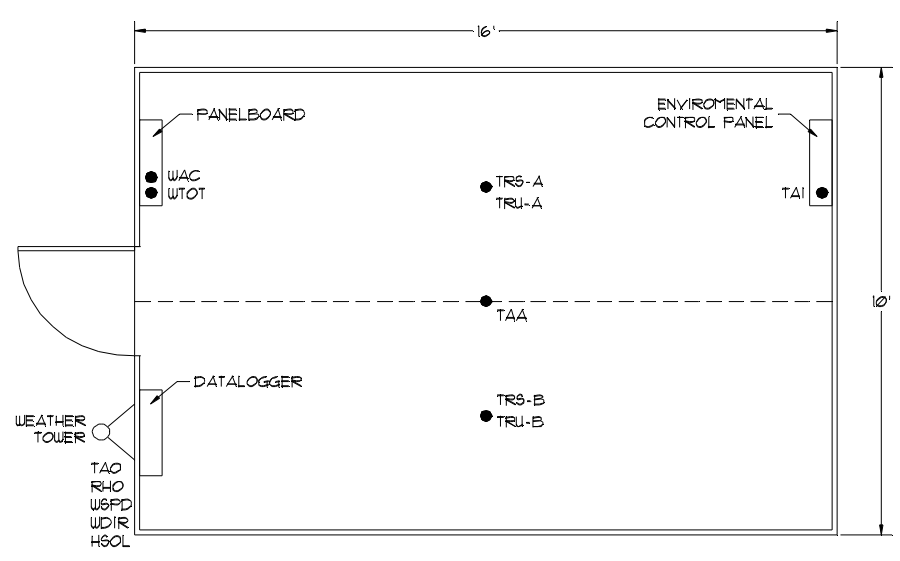

Figure 3: Monitoring Point Locations.

\section{Data Logger}

A Data Electronics DT50 data logger and a modem were installed on the wall inside each regen building (see Figure 4). All sensor cables were pulled to the logger box through a penetration in the ceiling. The modem was connected to the existing phone line for nightly data downloads. 


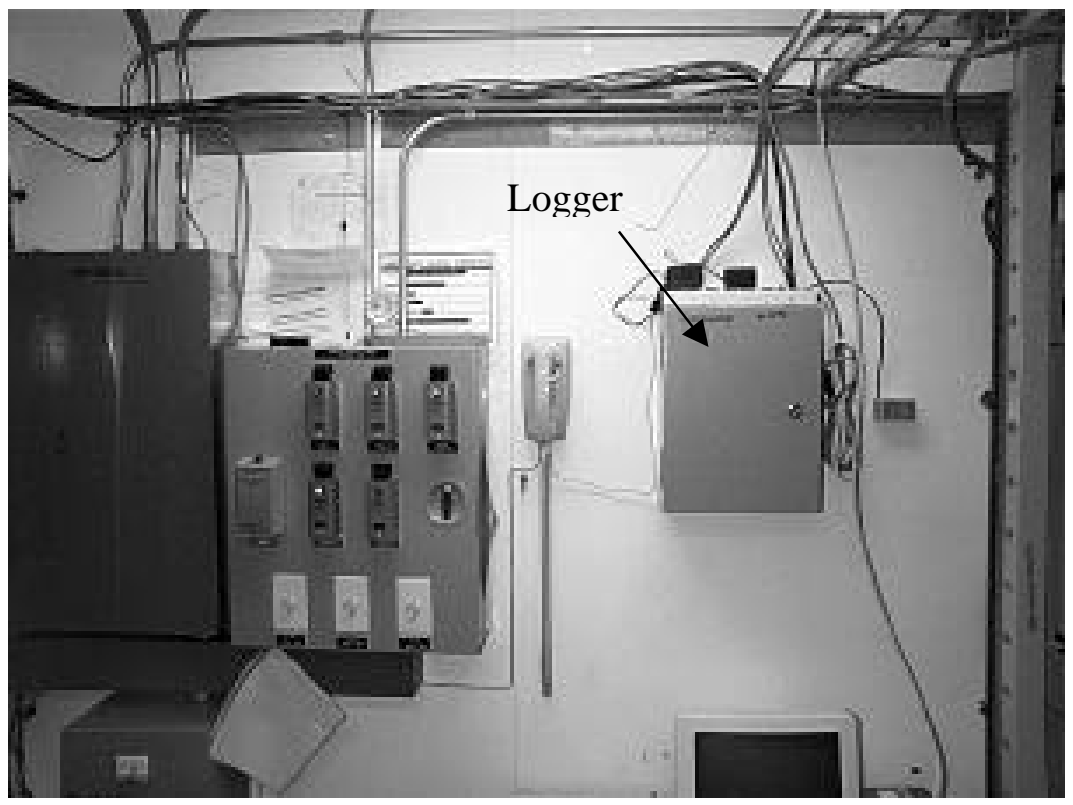

Figure 4: Data Logger Box

\section{Roof Temperature Sensors}

Two roof surface temperature sensors were installed, one in the middle of each side of the roof (see Figure 5). The sensors are type $\mathrm{T}$ foil thermocouples connected to special limits of error extension wire. The sensors were epoxied to the roof surface and then painted to match the existing roof color.

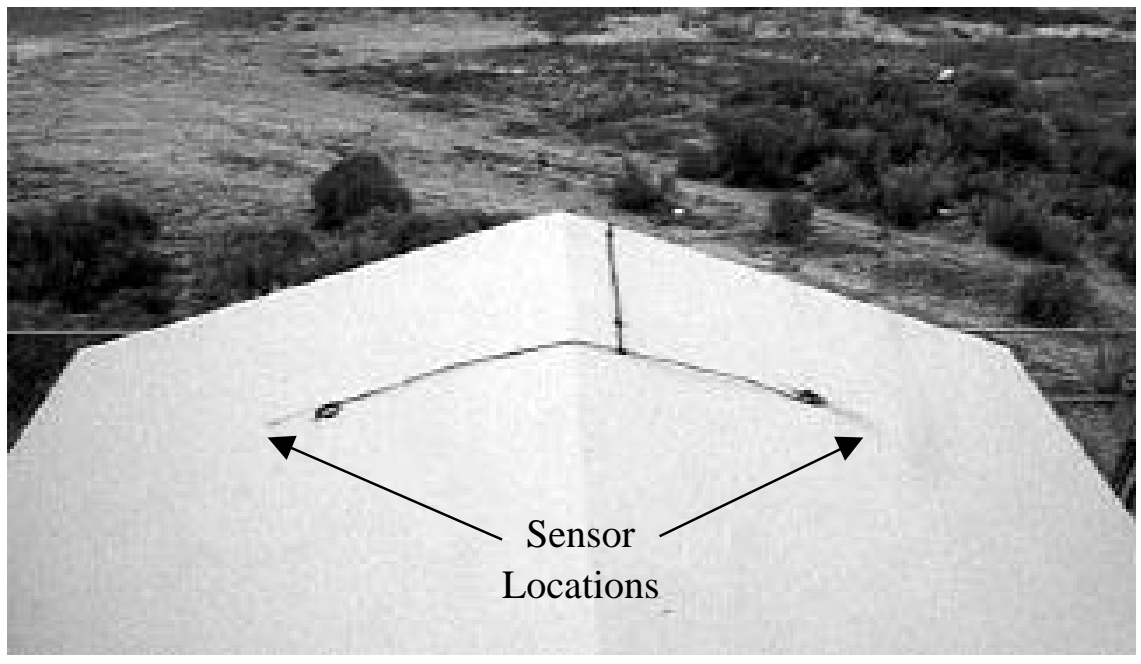

Figure 5: Roof Surface Temperature Sensors 


\section{Weather Tower}

A weather tower was attached to the side of the building, with the top $0.6 \mathrm{~m}$ (2') above the peak of the roof (see Figure 6). Mounted to the tower are an R.M. Young model 41372VF relative humidity/temperature probe in a gill radiation shield, an R.M. Young model 05103-11 wind monitor, and a Licor model LI-200SZ silicon pyranometer.

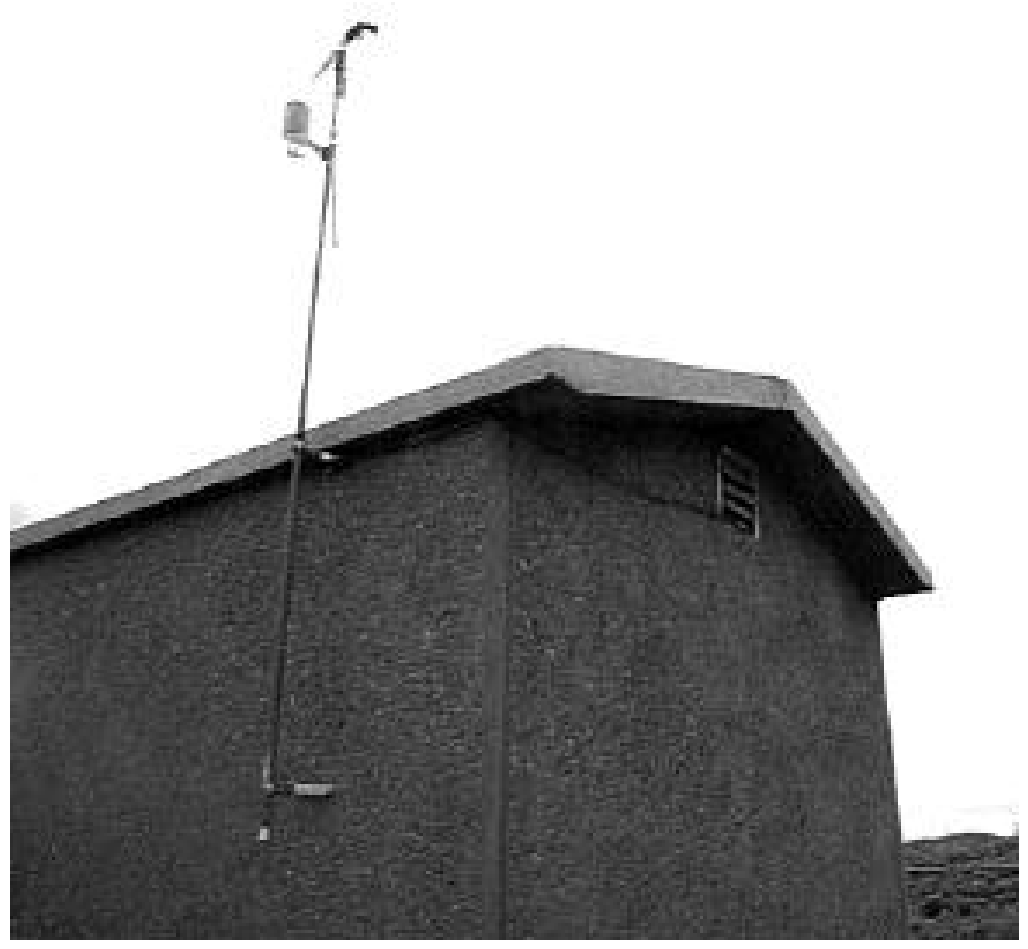

Figure 6: Weather Tower

\section{Interior Temperature Sensors}

Temperature sensors were installed directly below each of the two roof surface temperature sensors, in the attic space, and inside of the building (See Figures $\mathbf{7}$ and 8). The underside sensors were epoxied to the surface similarly to the roof surface sensors. The attic air temperature sensor was mounted in a shielded box to shield it from radiant transfer from the attic surfaces. The inside temperature sensor was mounted on the wall next to the environmental control panel. 


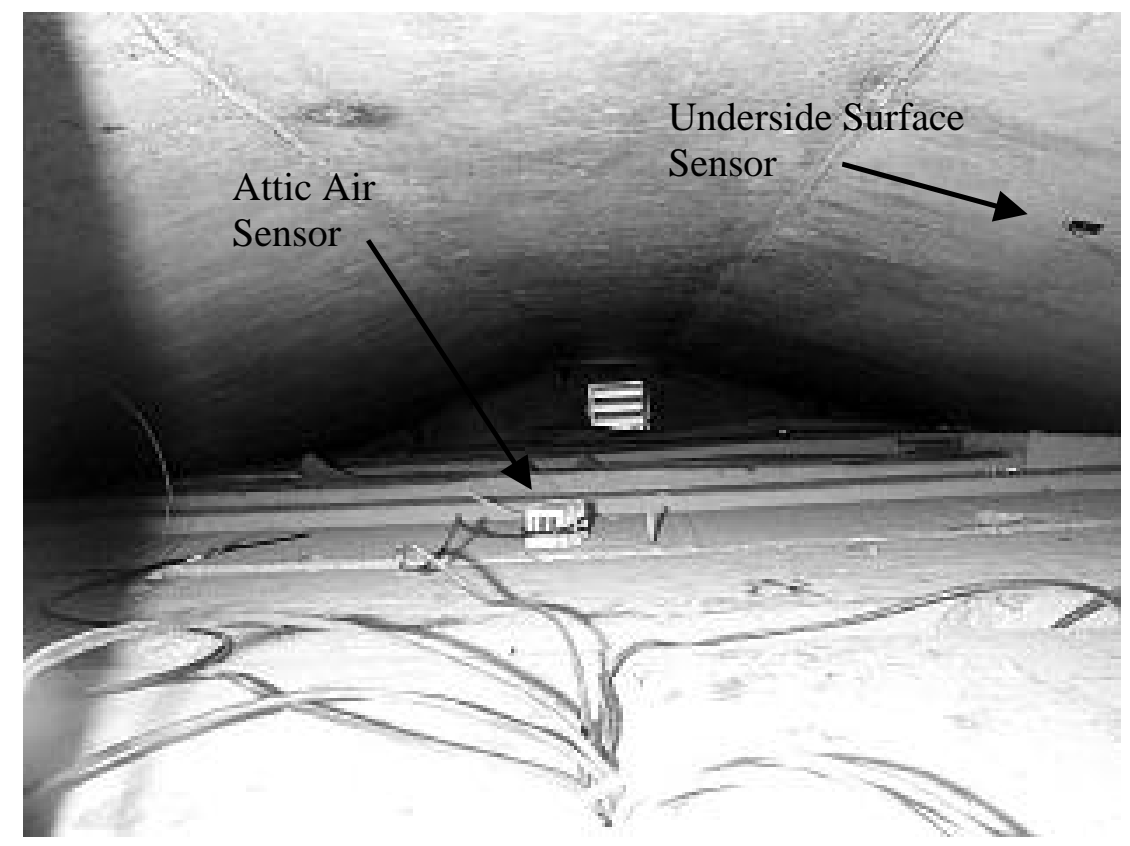

Figure 7: Underside and Attic Temperature Sensor Locations

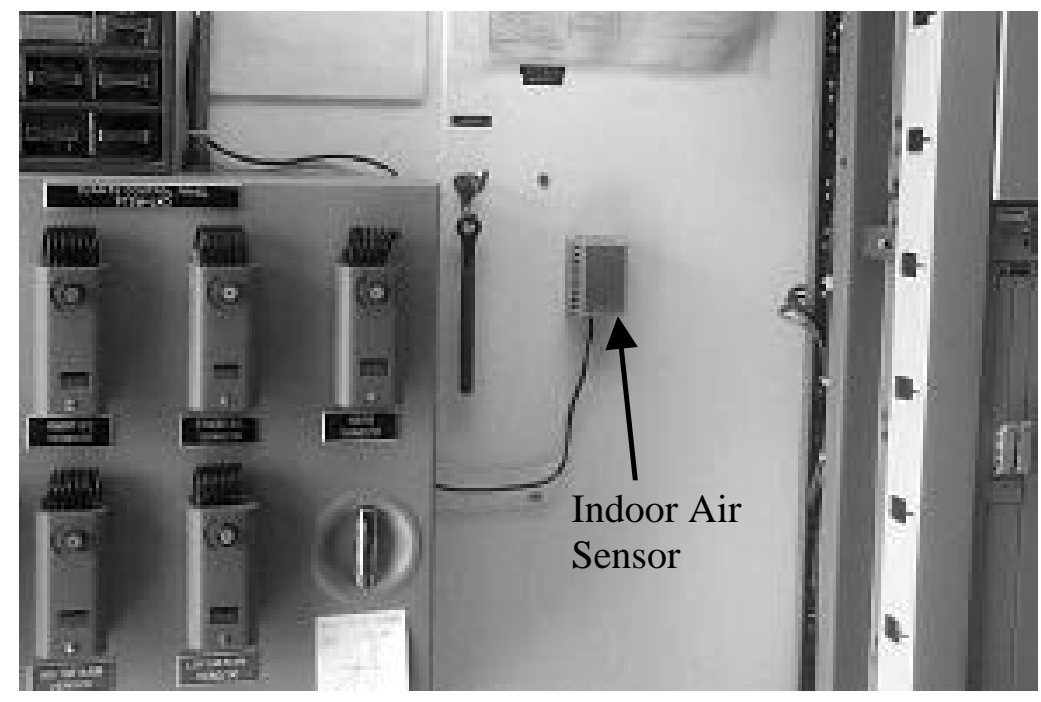

Figure 8: Indoor Air Sensor Location

\section{Power Transducers}

Two Continental Control Systems WNA-1P-240P power transducers were attached to the main building supply and both air-conditioning supplies. The transducers read both phases of current and voltage and provide 4 pulses per watt-hour (see Figure 9). 


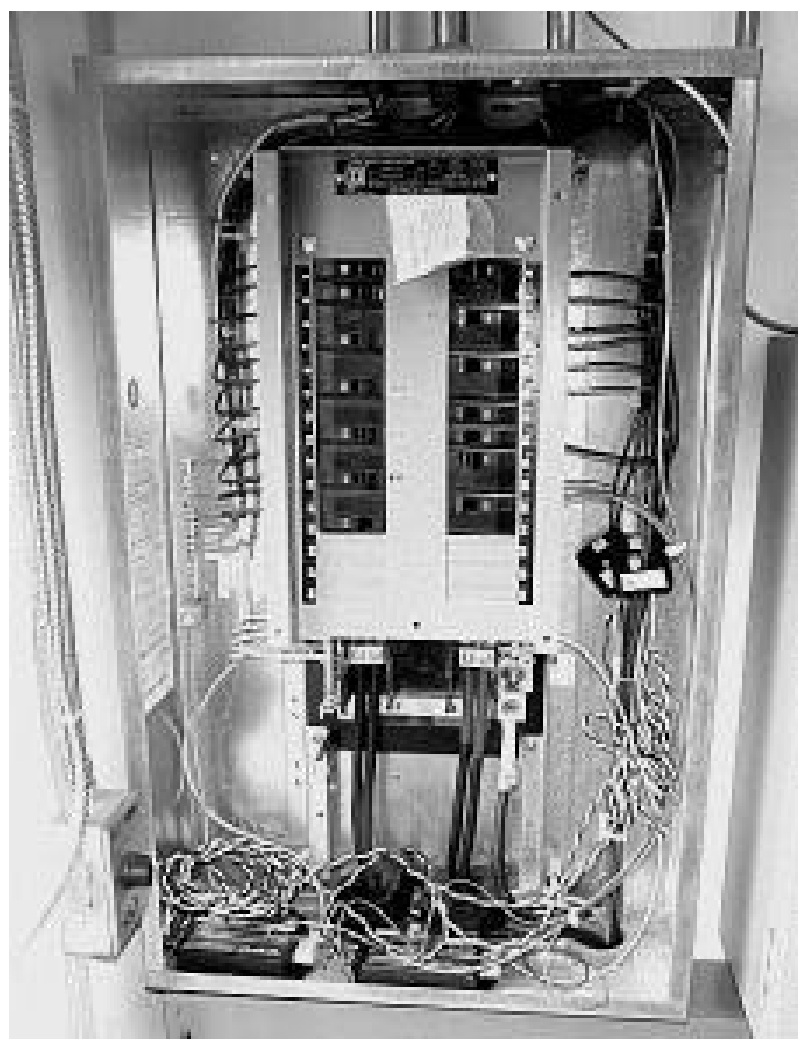

Figure 9: Power Transducers and Current Transformers

\section{Data Collection and Data Analysis Technique}

At all buildings, data were collected at 15-minute intervals. On a regular basis, the data were remotely downloaded to our computers for inspection and analysis. The data were frequently inspected for accuracy. Questionable and missing data were identified and flagged. In some cases, data indicated variations from standard operation of the buildings (e.g., lights were left on for a few days) and actions were taken to remedy the problem (e.g., lights were turned off).

The first step in the analysis was to aggregate the validated 15-minute data into hourly and daily data for solar intensity and for cooling and total energy use. The temperature data were averaged to yield hourly and daily variables. In this process, questionable and missing data were identified and excluded from the analysis.

The parameters that can affect air-conditioning energy use include outside temperature, inside temperature, solar heat gain, internal loads, relative humidity, and wind speed. A systematic regression analysis was performed in order to determine the sensitivity of the air-conditioning electricity use to these environmental parameters. The analysis was performed for the initial conditions before the roof was coated with a reflective white coating (defined as Pre period) and for the conditions after the roof was coated (defined as Post period). These regressions allowed normalizing the Pre and Post conditions for all parameters before making an attempt to estimate savings from the application of white coating. 


\section{Data Analysis and Results}

\section{Temperature Data}

Figure 10 shows the hourly temperature plots of the roof surface, under-roof surface, attic air and outside air for the three sites monitored. The dramatic impact of the roof coatings on the surface, undersurface and attic air temperatures is obvious. Before the roof coatings were applied, the roof surface temperatures were typically about $14-19 \mathrm{~K}\left(25-35^{\circ} \mathrm{F}\right)$ warmer than the ambient air temperature. The under-roof and attic temperatures were also consistently higher than the ambient air temperature. Even during the evening and early morning hours the roof, under-roof, and attic air were about $6 \mathrm{~K}\left(10^{\circ} \mathrm{F}\right)$ higher than ambient air; this is mostly because of the thermal storage effects of the concrete roofs. After the roof coatings were applied, the roof surface temperatures during daytime are about $19-22 \mathrm{~K}\left(35-40^{\circ} \mathrm{F}\right)$ cooler than the pre-retrofit conditions. In fact, in daytime, the roof surface temperatures are as much as $7 \mathrm{~K}\left(12^{\circ} \mathrm{F}\right)$ cooler than the ambient air temperatures. In nighttime hours, the roof surface temperatures are still cooler than the ambient air by a few degrees. The under-roof and attic air temperatures are very close to each other; during the day they are about $8-10 \mathrm{~K}$ $\left(15-18^{\circ} \mathrm{F}\right)$ cooler than the ambient air, during the night about $3 \mathrm{~K}\left(5^{\circ} \mathrm{F}\right)$ warmer than the ambient air.

Figure 11 is a plot of average daily and hourly temperature differences between reference and ambient temperature (temperature rise) for roof surface, under-roof, and attic air, for all 3 sites. It is evident that the average daily temperature rise for the roof surface before coating is $\sim 8 \mathrm{~K}\left(15^{\circ} \mathrm{F}\right)$. After coating, the average roof surface temperature is $\sim 2-3 \mathrm{~K}\left(3-5^{\circ} \mathrm{F}\right)$ cooler than the ambient air. The plot also shows changes in the temperatures of the roof layers on a diurnal basis.

A quick estimate of the impact of the roof coating on the air-conditioning energy use can be obtained from the analysis of the heat flow contribution through the roof. Data indicate that the average daily attic temperature before application of the roof coating is about $5 \mathrm{~K}\left(10^{\circ} \mathrm{F}\right)$ warmer than the daily ambient temperature. After the application of the roof coating, the daily attic temperature is about $2 \mathrm{~K}\left(3^{\circ} \mathrm{F}\right)$ cooler than the ambient temperature. This would yield an average daily temperature reduction of the attic air temperature by about $7 \mathrm{~K}\left(13^{\circ} \mathrm{F}\right)$. Given the ceiling R-value of $\mathrm{R}-18(7.5 \mathrm{~cm}$ of insulation), the reduction in the heat conducted through the roof is about $0.8 \mathrm{kWh}$ per day. Assuming an air-conditioning COP of about 2.0 (daily average), the net daily reduction in air-conditioning use is estimated to be about $0.4 \mathrm{kWh}$ per day. Since these buildings are conditioned throughout the year, assuming 250 sunny days during the year during which the light-colored coatings would keep the roof cool, the annual savings are estimated at about $100 \mathrm{kWh}$ per year for each of the buildings monitored. We will validate these early estimates later in this section by analyzing the monitored air-conditioning electricity use.

Also, it is important to note that the daily air-conditioning energy use for each of these buildings is about $35 \mathrm{kWh}$ (see the following section). Savings of about $0.4 \mathrm{kWh}$ per day because of the reflective roofs are about $1 \%$ of the total air-conditioning use. Documenting measured savings in the order of $1 \%$ is expected to be challenging.

\section{Air-Conditioning and Total Building Electricity Use}

In these buildings, we monitored the air-conditioning and the whole-building (total) energy use of the building. The energy use for the equipment inside the buildings was calculated by sub- 
Battle Mountain
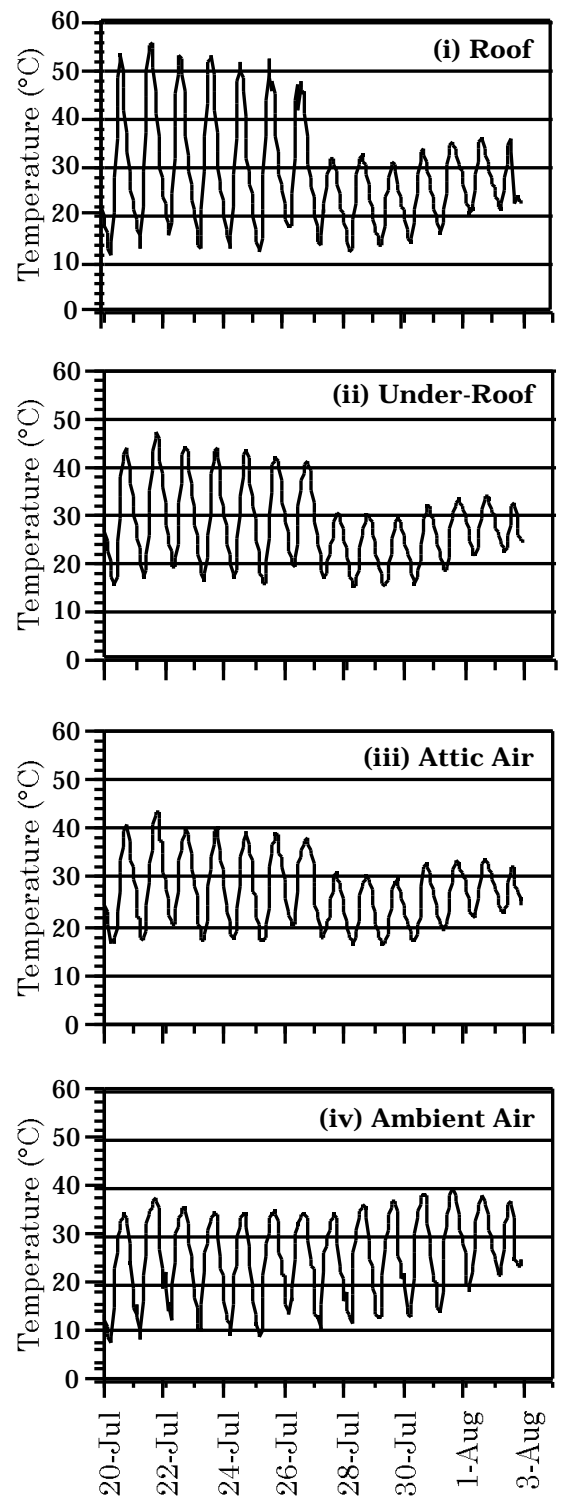

Carlin
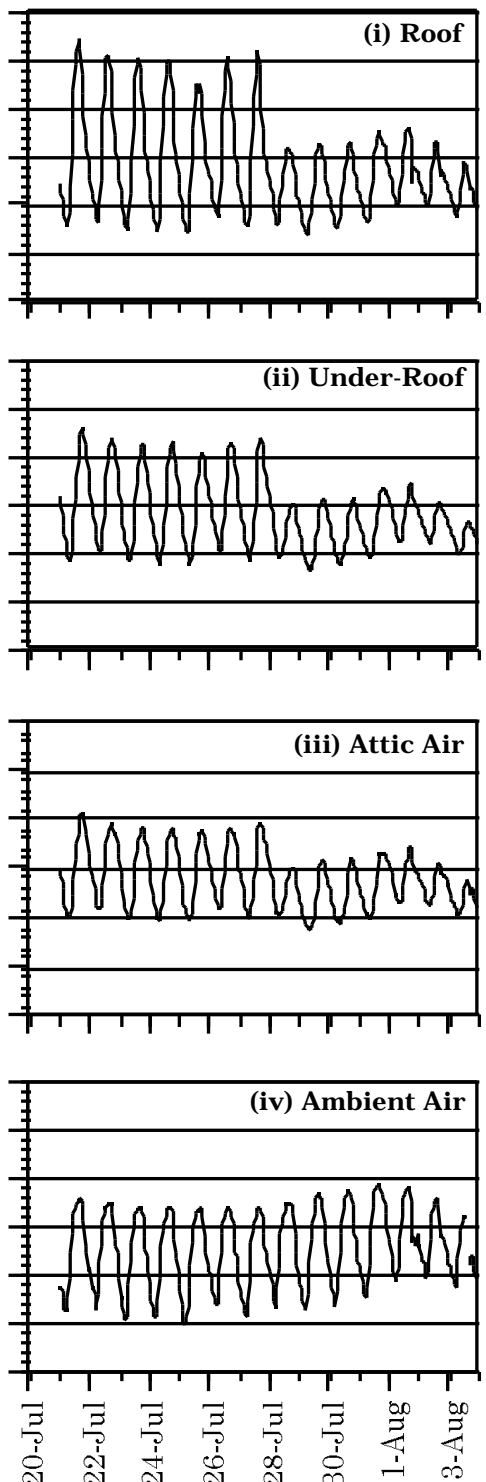

Washoe
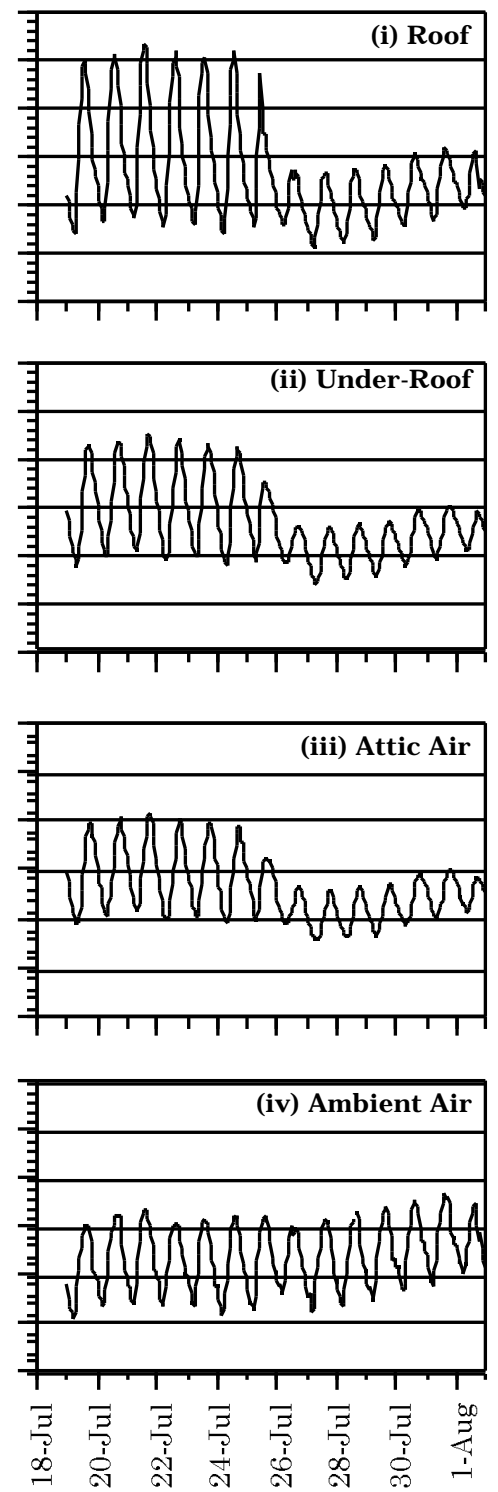

Figure 10. Hourly temperature plots of the roof surface, under-roof, and attic air and outside air for the three sites monitored. Hourly plots include a week before and after the roof was coated.

tracting the air-conditioning from the whole-building energy use. Figure 12 shows the whole-building, air-conditioning, and non-air-conditioning energy use data on a daily basis for the entire monitoring period, and on a hourly basis for a week before and after the roof coatings were applied.

Data for all three sites show a very constant level of energy use for non-air-conditioning equipment. This pattern of energy use for equipment was expected, since this equipment is in operation continuously. There are periods of exceptions to this constant energy use pattern. During most of the month of June (6/10-6/29), the building in Battle Mountain was using about $7 \mathrm{kWh}$ per day 
(a)
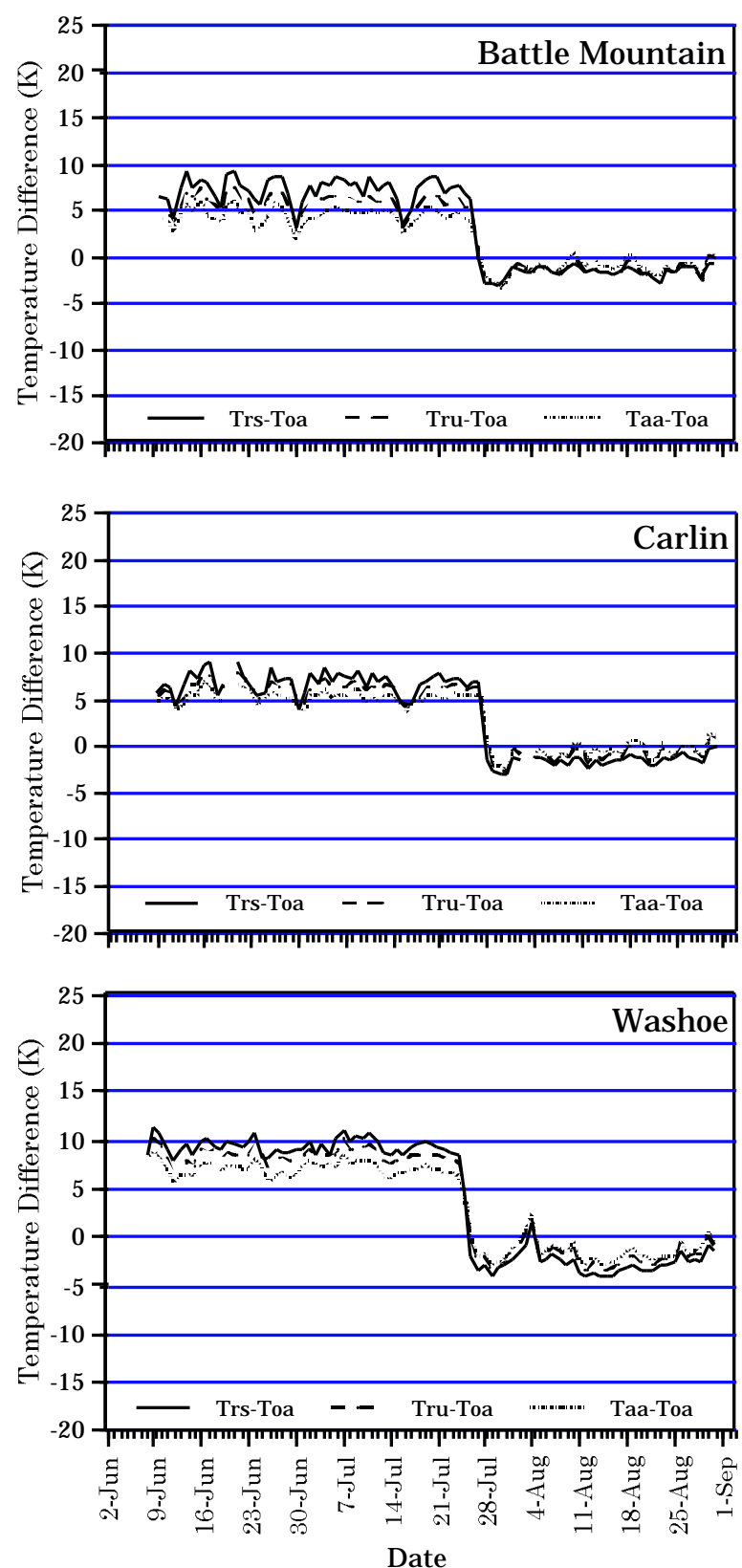

(b)
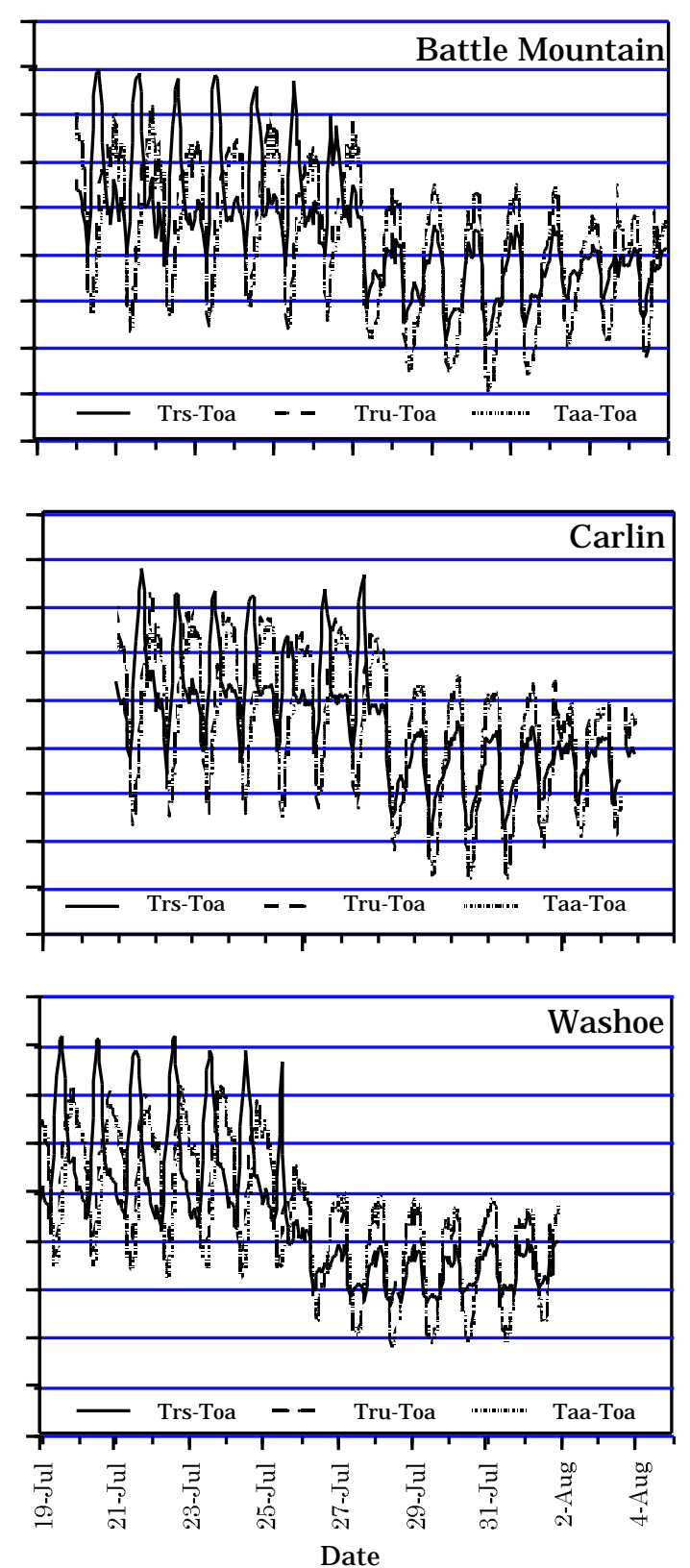

Figure 11. Daily average [a] and hourly [b] rises of roof surface temperature Trs, roof undersurface temperature Tru, and attic air temperature Taa above outside air temperature Toa. Hourly plots include a week before and after the roof was coated. 
(a)
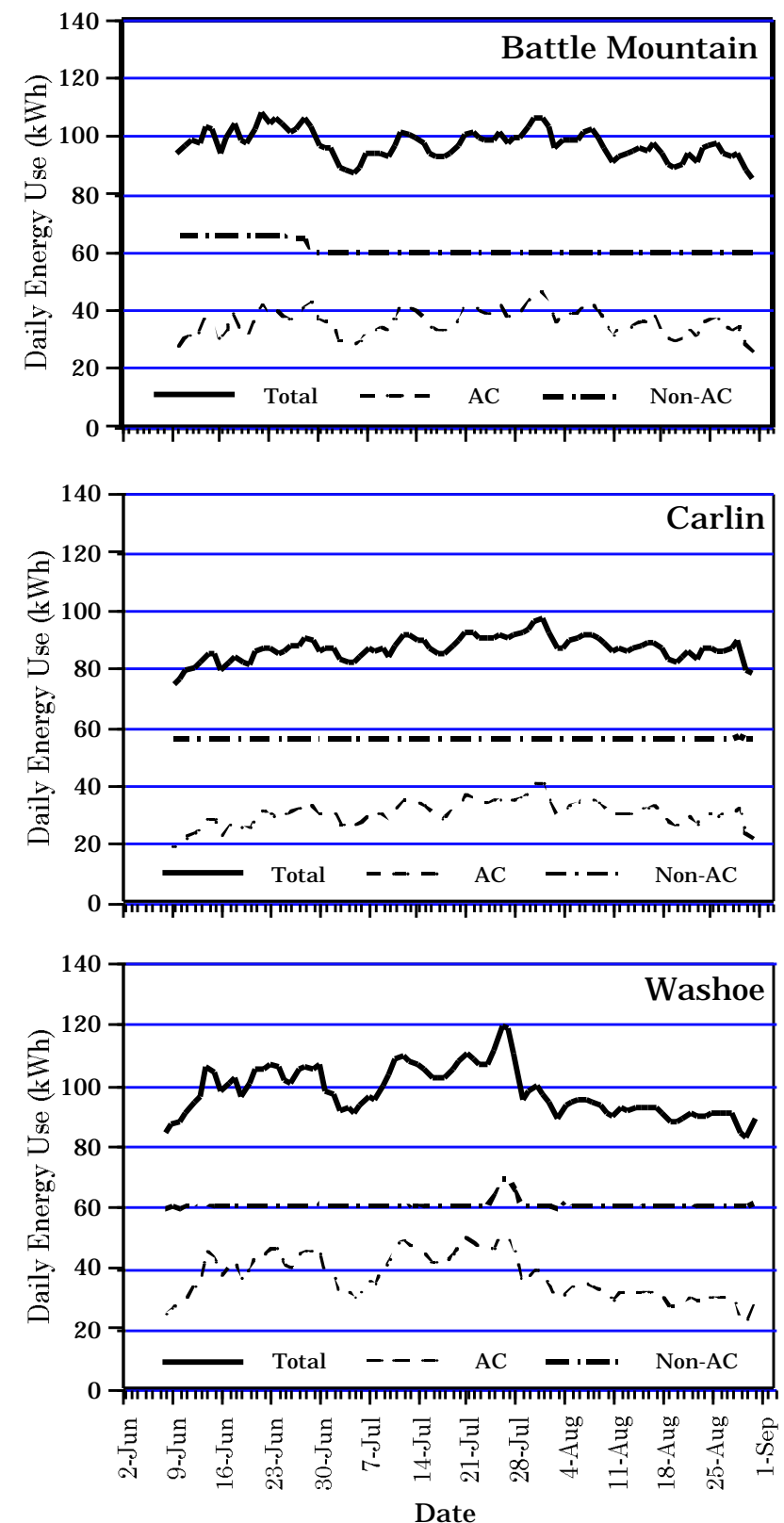

(b)
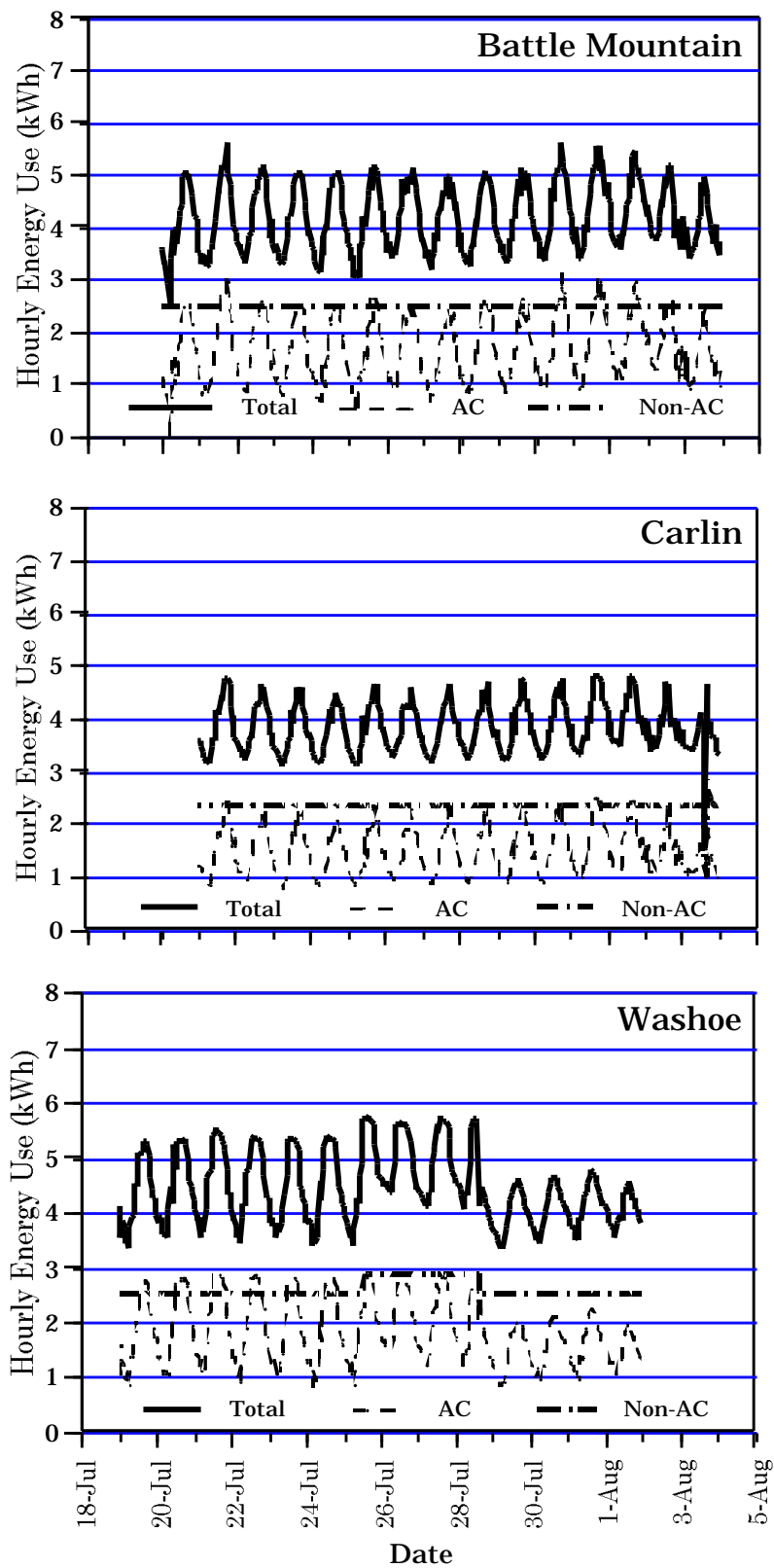

Figure 12. Daily [a] and hourly [b] total, air-conditioning (AC), and non-air-conditioning (nonAC) energy consumption.

more in equipment use than the rest of the monitoring duration. In the Washoe building, the interior lights were left on for four days after the roof was coated (7/25-7/28). The operators turned the lights off after we informed them of the problem. 
In the Battle Mountain and Carlin sites, the energy use for the air-conditioning shows no apparent change after the application of the roof coating. However, in the Washoe building, inspection of hourly data indicates a significant decrease (about $0.75 \mathrm{kWh} /$ hour) in AC energy use. This adds up to a total of about $18 \mathrm{kWh}$ per day. Obviously, this cannot be due to the roof coatings. A closer inspection of the AC systems indicates that this building is air-conditioned with two dissimilar AC units: one with a rated EER of 8.5 and the other with a rated EER of 9.2. We speculate that for some unknown reason(s), only the more efficient AC unit was operating for the period of July 27 to August 31.

\section{Analysis of Daily Air-Conditioning Energy Use}

To estimate the changes in air-conditioning energy use, we regressed the daily AC energy use against many variables, including the difference between inside and outside temperature, daily solar intensity, relative humidity, and wind speed. Of all these variables the regressions against the difference between the inside and outside temperature showed statistical significance. Also, to improve the regressions, we excluded the periods in which the internal loads were different than the typical operation. In Battle Mountain the excluded data were June 10-29 and in Washoe excluded data were July 25-28. ${ }^{2}$ These regressions are summarized and plotted in Figure 13.
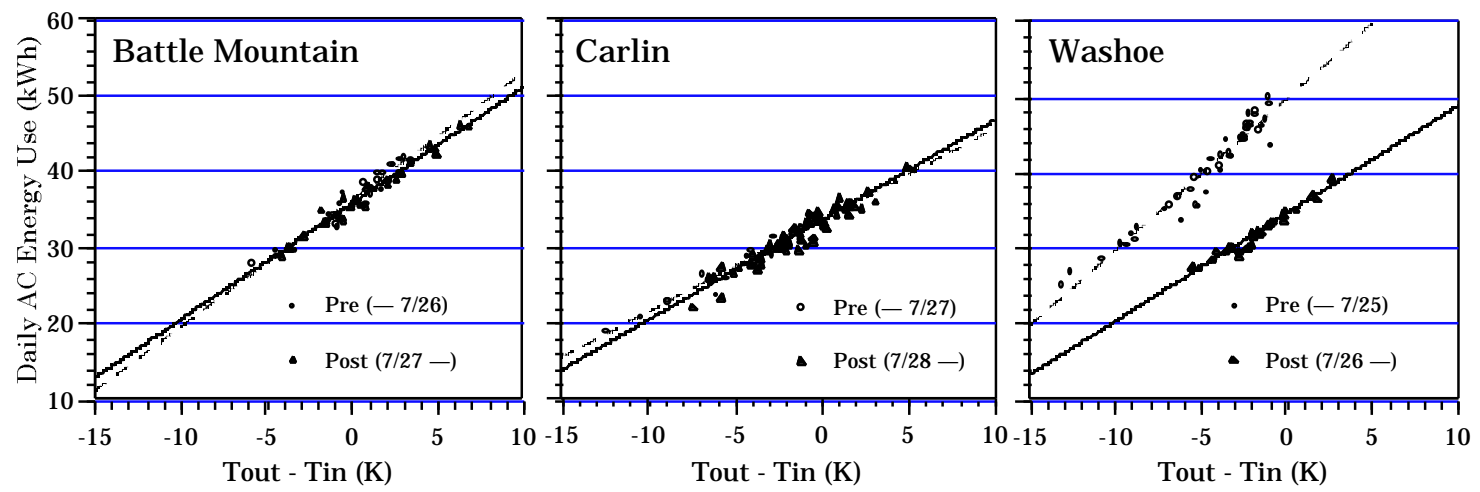

\begin{tabular}{|l|c|c|c|c|c|c|}
\hline & \multicolumn{2}{|c|}{ Battle Mountain } & \multicolumn{2}{c|}{ Carlin } & \multicolumn{2}{c|}{ Washoe } \\
\hline & Pre & Post & Pre & Post & Pre & Post \\
\hline $\mathrm{R}^{2}$ & 0.93 & 0.97 & 0.94 & 0.95 & 0.94 & 0.94 \\
\hline Intercept $(\mathrm{kWh})$ & 36.29 & 35.83 & 33.93 & 33.31 & 49.81 & 34.67 \\
\hline Slope $(\mathrm{kWh} / \mathrm{K})$ & 1.669 & 1.528 & 1.247 & 1.307 & 1.998 & 1.424 \\
\hline
\end{tabular}

Figure 13. Daily AC energy use vs. outside-inside temperature for pre- and post-coating.

As expected, the daily energy use for pre- and post-coating periods is very close for both buildings in Battle Mountain and Carlin. However, for the Washoe building, AC energy use for the Pre and Post periods is significantly different. We used correlations in Figure 13 to estimate the difference in AC energy use for the Pre and Post periods. These results are summarized in Figure 14.

\footnotetext{
${ }^{2}$ We initially tried to use the excluded data by adjusting the air-conditioning energy use for the changes in the interior load, using an estimate of the COP of the AC system from the normal operation of the building. However, the errors introduced through this approach were larger than the advantages of having more data points.
} 
In the Carlin building, where most data were 'clean,' the average estimated difference in AC energy use between the Pre and Post periods is about $0.76( \pm 0.18) \mathrm{kWh}$ per day. This compares favorably, with the earlier estimate of savings of about $0.4 \mathrm{kWh}$ per day, using the heat conduction

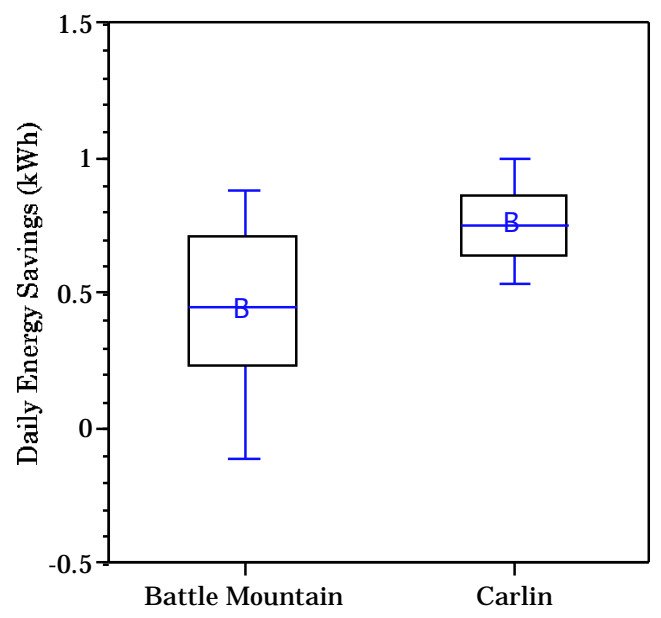

Figure 14. Daily energy savings at Battle Mountain and Carlin from the application of reflective roof coatings. Lines represent $10^{\text {th }}, 25^{\text {th }}, 50^{\text {th }}, 75^{\text {th }}$, and $90^{\text {th }}$ percentiles; symbols are means.

formula through the roof. The estimated savings for over $90 \%$ of the days are in the range of 0.53 $1.00 \mathrm{kWh}$ per day. For the Battle Mountain building, the average estimated savings are about 0.44 $\mathrm{kWh}( \pm 0.25) \mathrm{kWh}$ per day, compared to $0.4 \mathrm{kWh}$ estimated using the heat conduction formula. Obviously, since the Battle Mountain building was not heated during this period, the negative savings shown in Figure 14 are the results of the statistical analysis. In this building, we estimated positive savings for over $88 \%$ of the days.

The difference between the Pre and Post periods for the Washoe building (not shown in Fig. 14) averaged about $13.1 \mathrm{kWh}$ per day. This difference is much larger than the theoretical estimate and measured savings in the other two buildings. The Washoe building is conditioned with two dissimilar AC systems, one with an EER of 8.5 and the other with an EER of 9.2. The capacities of these two units are also different. We speculate that during the Pre period the building was conditioned with the AC unit of lower efficiency and for the Post period with the more efficient one. At any rate, these measured savings indicate the importance of selecting an AC unit of the proper size and specification, as these factors significantly affect energy consumption.

\section{Analysis of Hourly Air-Conditioning Energy Use}

We also tried to estimate savings from the regressions of hourly AC energy use vs. the outside/inside temperature difference; these regressions are presented in Figure 15. For both the Battle Mountain and Carlin buildings the slope of the fits was about the same in pre- and post-coating periods (Battle Mountain $46.1 \mathrm{~W} / \mathrm{K}\left[25.6 \mathrm{~W} /{ }^{\circ} \mathrm{F}\right]$ vs. $46.4 \mathrm{~W} / \mathrm{K}\left[25.8 \mathrm{~W} /{ }^{\circ} \mathrm{F}\right]$ ) and for Carlin $62.6 \mathrm{~W} / \mathrm{K}$ $\left[34.8 \mathrm{~W} /{ }^{\circ} \mathrm{F}\right]$ vs. $61.9 \mathrm{~W} / \mathrm{K}\left[34.4 \mathrm{~W} /{ }^{\circ} \mathrm{F}\right]$, a difference of about $1 \%$ in slopes). The regressions' intercepts for both buildings were lower (by about 20W/hour) in the post-coating than those of the pre-coating (Battle Mountain: Pre $=1.500 \mathrm{~kW} v s$. Post: $1.481 \mathrm{~kW}$; Carlin: $1.397 \mathrm{~kW} v s$. Post $=1.374 \mathrm{~kW}$ ). The re- 
gressions for the Washoe building clearly show a reduction in AC energy use for the Post period that cannot be explained by the impact of the roof coating.

We used the regression coefficients to estimate differences in energy use between the preand post-coating periods; the results are shown in Table 4. The mean and median hourly savings for Battle Mountain and Carlin are $19( \pm 6) \mathrm{Wh} / \mathrm{h}$ and $24( \pm 3) \mathrm{Wh} / \mathrm{h}$, respectively. The daily savings are estimated at $0.46( \pm 0.14) \mathrm{kWh}$ and $0.58( \pm 0.07) \mathrm{kWh}$ (the average for these two buildings is about $0.52 \mathrm{kWh} /$ day). These savings compare well with savings of $0.4 \mathrm{kWh}$ per day estimated from the heat conduction formula.

For the Washoe building, the mean and median difference in hourly AC energy use is about $0.55( \pm 0.21) \mathrm{kWh} / \mathrm{h}$; the daily difference is about $13.4( \pm 5) \mathrm{kWh} /$ day. This difference most likely resulted from the difference in the EER of the two dissimilar AC units.
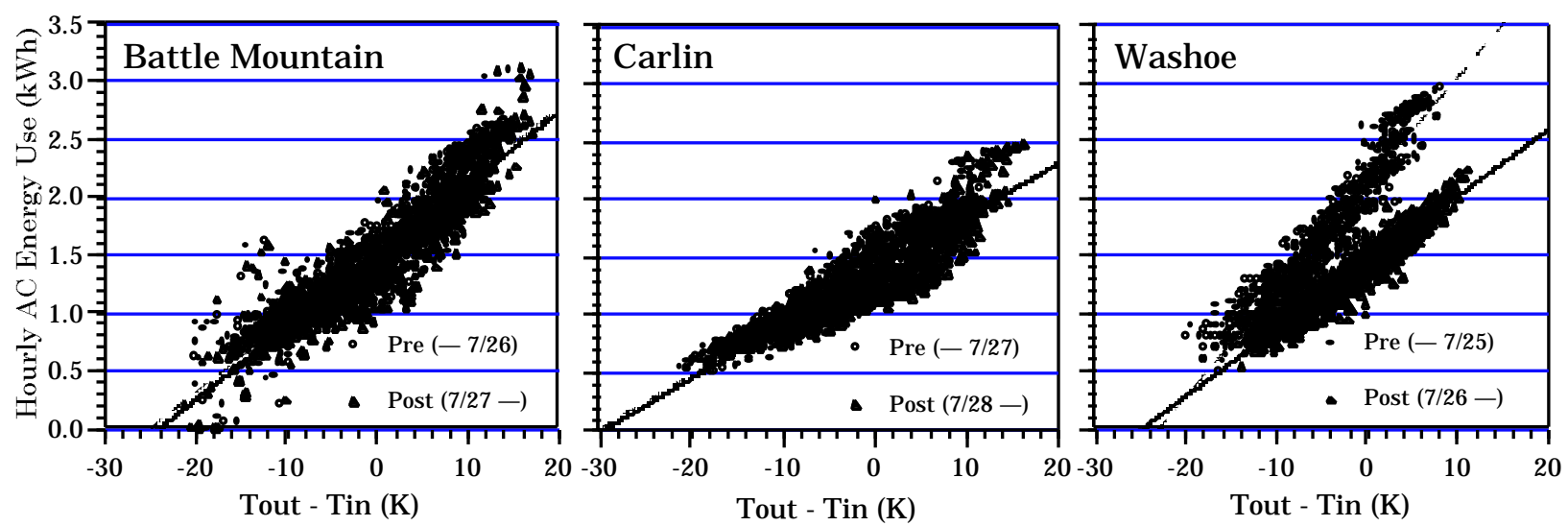

\begin{tabular}{|l|c|c|c|c|c|c|}
\hline & \multicolumn{2}{|c|}{ Battle Mountain } & \multicolumn{2}{c|}{ Carlin } & \multicolumn{2}{c|}{ Washoe } \\
\hline & Pre & Post & Pre & Post & Pre & Post \\
\hline $\mathrm{R}^{2}$ & 0.87 & 0.85 & 0.83 & 0.83 & 0.90 & 0.91 \\
\hline Intercept $(\mathrm{kWh})$ & 1.500 & 1.481 & 1.397 & 1.374 & 2.117 & 1.433 \\
\hline Slope $(\mathrm{Wh} / \mathrm{K})$ & 62.6 & 61.9 & 46.1 & 46.4 & 92.3 & 58.0 \\
\hline
\end{tabular}

Figure 15 . Hourly AC energy use vs. outside-inside temperature for pre- and post-coating.

\section{Summary and Conclusions}

Energy use and environmental parameters were monitored in three AT\&T regeneration buildings during the summer of 2000 (June 10 to October 5). These buildings are constructed of concrete and are about $14.9 \mathrm{~m}^{2}$ in size $\left(160 \mathrm{ft}^{2}, 10 \mathrm{x} 16 \mathrm{ft}\right)$. The buildings were initially monitored for about $11 / 2$ months (June 10 to about July 25) to establish a base condition. Then, the originally green roofs of the buildings were painted with a white coating (July 25 to July 27) and the monitoring was continued. The original roof reflectances were about 26\%; after the application of the roof coatings, the reflectivities increased to about $72 \%$. 
Table 4: Mean and median hourly savings $(\mathbf{k W h} / \mathbf{h})$. For the Washoe building, the savings most likely resulted from the difference in the EER of the two dissimilar AC units.

\begin{tabular}{l|c|c|c} 
Savings (kWh/h) & Washoe & Carlin & $\begin{array}{c}\text { Battle } \\
\text { Mountain }\end{array}$ \\
\hline Min & -0.003 & 0.017 & 0.004 \\
\hline 5-percentile & 0.234 & 0.020 & 0.010 \\
\hline 10-percentile & 0.294 & 0.020 & 0.011 \\
\hline 1-quartile & 0.404 & 0.022 & 0.014 \\
\hline Med & $\mathbf{0 . 5 5 1}$ & $\mathbf{0 . 0 2 4}$ & $\mathbf{0 . 0 1 9}$ \\
\hline Mean & $\mathbf{0 . 5 6 2}$ & $\mathbf{0 . 0 2 4}$ & $\mathbf{0 . 0 1 9}$ \\
\hline 3-quartile & 0.738 & 0.026 & 0.024 \\
\hline 90-percentile & 0.851 & 0.028 & 0.027 \\
\hline 95-percentile & 0.891 & 0.029 & 0.028 \\
\hline Max & 1.063 & 0.031 & 0.032
\end{tabular}

In two of these buildings, the analysis of monitored hourly data showed savings of about $0.5 \mathrm{kWh}$ per day $\left(30 \mathrm{Wh} / \mathrm{m}^{2}\left[3 \mathrm{Wh} / \mathrm{ft}^{2}\right]\right)$. Since these building are air-conditioned over 250 days of the year, the annual energy savings are estimated at about $125 \mathrm{kWh}\left(7 \mathrm{kWh} / \mathrm{m}^{2}\left[0.7 \mathrm{kWh} / \mathrm{ft}^{2}\right]\right)$. The third building showed a reduction in air-conditioning energy use of about $13 \mathrm{kWh}$ per day (860 $\left.\mathrm{Wh} / \mathrm{m}^{2}\left[80 \mathrm{Wh} / \mathrm{ft}^{2}\right]\right)$. These savings probably resulted from the differences in the performance (EER) of the two dissimilar AC units in this building.

The estimated annual savings for the Battle Mountain and the Carlin buildings is about $125 \mathrm{kWh}$ per year; at $\$ 0.1 / \mathrm{kWh}$, savings are about $\$ 12.5$ per year. Obviously, it cost significantly more than this amount to coat the roofs with reflective coating, particularly because of the remote locations of these buildings. However, since the pre-fabricated roofs are already painted green at the factory, painting them with white (reflective) color would bring no additional cost. Hence the payback time for having reflective roofs is nil, and the reflective roofs save an accumulated $3750 \mathrm{kWh}$ over 30 years of the life of the roof, assuming that the roof maintains its reflectivity over the 30 year life of the roof.

In one of these buildings, we monitored savings in excess of $25 \%$ that resulted from a highperformance AC system. Since many of the AC units at the regeneration buildings need to be constantly maintained and repaired, a program of replacing older inefficient units with more efficient ones at the time of maintenance can save over $\$ 300$ per year at each site.

\section{Acknowledgements}

This work was supported by AT\&T, the U.S. Environmental Protection Agency (EPA) under IAG No. DW89938442-01-2, and by the Assistant Secretary for Energy Efficiency and Renewable Energy, Building Technologies, of the US Department of Energy (DOE) under contract No. DEAC03-76SF00098. The authors would like to thank Mr. Bart Miller and other staff at AT\&T for assistance throughout this project. We also acknowledge assistance of Steve Konopacki for data collection and analysis, and of Ronnen Levinson for preparation of graphs. 


\section{References}

Akbari, H., S. Bretz, D. Kurn and J. Hanford. 1997. "Peak Power and Cooling Energy Savings of High-Albedo Roofs.” Energy and Buildings 25:117-126.

Akbari, H., S. Konopacki, C. Eley, B. Wilcox, M. Van Geem and D. Parker. 1998. "Calculations for Reflective Roofs in Support of Standard 90.1.” ASHRAE Transactions 104(1):984-995.

Akridge, J. 1998. "High-Albedo Roof Coatings-Impact on Energy Consumption." ASHRAE Technical Data Bulletin 14(2).

Boutwell, C. and Y. Salinas. 1986. "Building for the Future-Phase I: An Energy Saving Materials Research Project." Oxford: Mississippi Power Co., Rohm and Haas Co. and the University of Mississippi.

Gartland, L., S. Konopacki and H. Akbari. 1996. "Modeling the Effects of Reflective Roofing." Proceedings, ACEEE 1996 Summer Study on Energy Efficiency in Buildings 4:117-124. Pacific Grove, CA.

Hildebrandt, E., W. Bos and R. Moore. 1998. "Assessing the Impacts of White Roofs on Building Energy Loads." ASHRAE Technical Data Bulletin 14(2).

Konopacki, S. and H. Akbari. 2000. "Energy Savings Calculations for Heat Island Reduction Strategies in Baton Rouge, Sacramento and Salt Lake City.” Lawrence Berkeley National Laboratory Report LBNL-42890. Berkeley, CA.

Konopacki, S. and H. Akbari. 1998. "Simulated Impact of Roof Surface Solar Absorptance, Attic, and Duct Insulation on Cooling and Heating Energy Use in Single-Family New Residential Buildings." Lawrence Berkeley National Laboratory Report LBNL-41834. Berkeley, CA.

Konopacki, S., H. Akbari, L. Gartland and L. Rainer. 1998. "Demonstration of Energy Savings of Cool Roofs.” Lawrence Berkeley National Laboratory Report LBNL-40673. Berkeley, CA.

Konopacki, S., H. Akbari, M. Pomerantz, S. Gabersek and L. Gartland. 1997. "Cooling Energy Savings Potential of Light-Colored Roofs for Residential and Commercial Buildings in 11 U.S. Metropolitan Areas." Lawrence Berkeley National Laboratory Report LBNL-39433. Berkeley, CA.

Parker, D., J. Huang, S. Konopacki, L. Gartland, J. Sherwin and L. Gu. 1998. "Measured and Simulated Performance of Reflective Roofing Systems in Residential Buildings." ASHRAE Transactions 104(1):963-975.

Parker, D., J. Sonne and J. Sherwin. 1997. "Demonstration of Cooling Savings of Light Colored Roof Surfacing in Florida Commercial Buildings: Retail Strip Mall.” Florida Solar Energy Center Report FSEC-CR-964-97. Cocoa, FL. 